\title{
Deviant behaviour? Inequality in Portugal 1565-1770
}

\author{
Jaime Reis ${ }^{1}$ (D)
}

Received: 13 May 2016/ Accepted: 10 October 2016

(C) Springer-Verlag Berlin Heidelberg 2016

\begin{abstract}
This study offers an estimate of Portuguese income inequality over a period of more than 200 years. It is presented in three widely spaced benchmarks: 1565,1700 and 1770 . This entirely new index is based in large measure on a littleresearched annual personal income tax (décima) instituted in 1641. It covered all social classes, including nobility and clergy and every form of household earnings, and permits therefore a singularly accurate measure. It allows us to conclude that, in contrast with early modern Europe in general, Portugal experienced a notable decline in economic inequality. Several freshly minted quantitative indicators enable us to conclude that the burden of the explanation for this apparently 'deviant' behaviour can be ascribed to changes in the functional distribution of income. Significant transformations in Portuguese agriculture-towards labour-intensive products like maize and wine-permanently shifted the wage-rental ratio in favour of labour. The skill premium fell but its contribution was relatively modest. It was a time of sustained economic growth, but this was not associated with pronounced urbanization or industrialization.
\end{abstract}

Keywords Inequality $\cdot$ Early modern $\cdot$ Portugal $\cdot$ Kuznets curve $\cdot$ Factor-price ratios

JEL Classification N13 · N33

Jaime Reis

jaime.reis@ics.ul.pt

1 Instituto de Ciências Sociais, Universidade de Lisboa, Lisbon, Portugal 


\section{Introduction}

Economic inequality in early modern Europe has attracted a considerable amount of attention in the last twenty years or so. This rise to prominence has occurred concurrently with another important wave of scholarly endeavour dealing with the long-run macroeconomic performance of nations. Both literatures are quantitative, require a substantial data gathering effort and use economic tools of analysis. Together, they represent a major new approach to our understanding in the past of the two most important issues of our time: economic growth and how its results are distributed. Yet, to date they have not developed much in terms of the historical relations between them. The present paper belongs in the second of these fields of inquiry but takes advantage of progress in the first.

A vigorous data-mining effort conducted during these two decades has encompassed many configurations - countries, regions, cities, towns, villages and rural spaces - and stretched across smaller or larger parts of the three centuries considered. This accumulation of findings has motivated retroactive estimations comparing the earlier modern era with the present. Others have traced the causes of present-day inequality, including in former colonial territories all the way back to the historical experience of their former European masters. ${ }^{1}$

Of particular significance are two influential papers that have shaped the debate concerning the evolution of inequality over long periods. One of these-van Zanden (1995)_-gets its inspiration from Kuznets' famous inverted U-shaped curve representing economic inequality during the era of modern economic growth. Early modern growth in dynamic countries like Holland and England was probably driven by similar mechanisms and caused a sustained rise in income disparity. This was overlaid by shifts in the functional division of income caused also by economic development and with similar effects.

A second path-breaking approach came some years later. Major contributions by Williamson (2009) and Milanovic et al. (2011) suggested that the degree of economic inequality at any point in time and space was not only positively correlated with its level of per capita income. It was also connected with the varying ability of elites to extract resources from the above-subsistence surplus produced by the community. For this, they used a variety of political and economic means at their disposal. The importance of this contribution is that variation in inequality thus ceased to be understood as mainly endogenous to growth, as in Van Zanden's work (1995), and could now be understood also as dependent on the exogenous impact of power and institutions on distribution.

Notwithstanding the treasure trove of data and ideas for understanding them, progress in the analysis of economic inequality has not been as great as one might have expected. There are two problematic areas here. One is that consistent "country studies' covering long periods of time-as Kuznets presumed for his modelremain scarce. Moreover, they often lack the macroeconomic indicators needed for testing the application of theory to history. This is particularly so with the numerous microeconomic studies in this field. The other is that, although the proxies employed

\footnotetext{
${ }^{1}$ A classic work on this problematic is Engerman and Sokoloff (1997).
} 
to estimate wealth or income disparity are abundant, the measures for them are not always sufficiently homogeneous in conceptual, methodological and empirical terms. This makes it difficult to establish valid cross-country, inter-temporal comparisons in this field.

This paper presents a case study of income disparity in Portugal from the midsixteenth to the late eighteenth centuries. It is based on a sizeable body of largely unexplored fiscal data, which provides a considerable amount of detail on income drawn from personal tax rolls. It also assures a wide coverage of the country. This allows us to establish a reasonably accurate national account of inequality, as opposed to the local or regional inequality estimates more commonly seen in this context. Estimates of income inequality are undertaken for three benchmarks1565, 1700 and 1770. Portugal is of interest for other reasons, however. From the present point of view, it is seriously under-studied and constitutes therefore a relevant gap in the global European picture. Moreover, as recent research has shown (Palma and Reis 2016), in terms of long-term economic performance, it is neither an outlier nor a laggard and therefore is reasonably representative of a European 'norm'.

The present research makes two contributions to the burgeoning literature on pre-industrial economic inequality. The first is methodological. It shows how a measure of national inequality can be constructed for a prolonged period by obtaining Theil indices from a limited set of representative local observations and then aggregating them. Consistent and reliable results can thus be achieved using relatively scarce resources. The second is its fresh and challenging results, mainly that Portugal displayed a persistent decrease in national inequality between the sixteenth and the eighteenth centuries. At a time of mostly positive macroeconomic performance, this would seem to point in the opposite direction to that of the canonical perspective.

The analysis of this conundrum relies on three ideas, which are not new in the literature but have led in other cases to different interpretations. The first appeals to the oft-invoked primacy of variation in the functional distribution of income to explain changes in economic inequality. The second idea is that the country recorded substantial growth, but this was accompanied by relatively little structural change. The impact of urbanization, capital concentration and escalating demand for skills found, for example, in Holland, was only weakly felt in Portugal. The third belongs to the realm of political economy. It relates to the significant rise in income from empire accruing to the crown and to the elites and to the country's relatively low military effort in the long run. Any of these factors might have lessened the need, comparatively, for these extractive groups to pressure the lower economic strata of Portuguese society.

\section{Portugal: a data set and a methodology}

Economic inequality in twentieth century Iberia has attracted considerable attention recently. This is not surprising given the region's history of political extremes in this period and the links between political contexts and inequality. In Spain, this interest 
has spilled back in time, and the result is a fairly clear picture for the Early Modern period too (Santiago-Caballero 2011; Alvarez-Nogal and Prados de la Escosura 2013; Nicolini and Ramos-Palencia 2016). Recent studies on Portugal have also placed it on the world's twentieth century inequality map (Guilera 2010; Lains et al. 2008; Alvaredo 2008), but the same cannot be claimed for earlier periods.

In the earlier, non-quantitative literature, Portuguese was seen as profoundly unequal, with the vast majority living in abject poverty and a tiny minority of nobles, high clergy and rich merchants controlling enormous shares of national income. This was deemed a major barrier to long-term economic growth (Godinho [1971] 1980). The literature also recognized that these asymmetries were not static but followed a rough periodization. The pre-1500 period was described as 'democratic', with a low degree of inequality. This increased during the sixteenth century due to imperial expansion and happened again during the eighteenth century owing to a second burst of colonial enlargement. In between, inequality declined, thanks to the capacity of the urban bourgeoisie to break the grip of the nobility on trade (Cortesão 1964; Serrão 1969).

None of these interpretations has been supported by either empirical evidence or the correct analytic tools, nor have they added much to our understanding of historical distributional issues. The exception is Johnson's (2002) pioneering work based on a large collection of evidence from the Middle Ages to $1800 .^{2}$ Our research follows Johnson's footsteps but with three modifications. The first is to set aside the pre-1500 material and replace part of the later pool of its sources by a larger and richer body of fiscal data, as yet unexplored. ${ }^{3}$ The second focuses on three benchmark years separated by long intervals, rather than attempt something closer to a time series. We have chosen 1565, in the midst of the first burst of overseas expansion; 1770, towards the end of Portugal's second great colonial cycle; and 1700, an intermediate point in the country's long-term spurt of economic growth from 1600 to the 1750 s. The third modification concerns the method whereby the variety of local measurements is pulled together into a single, representative national metric. The Theil index adopted here, which is not inferior to the Gini index in other respects, has the advantage of being decomposable. ${ }^{4}$ It can thus serve for averaging local estimates in order to obtain a comprehensive measurement without bias, something that using a Gini would not allow. ${ }^{5}$

Of the three standard source materials for studying early modern economic inequality, only one can be used in early modern Portugal. ${ }^{6}$ Social tables have not

\footnotetext{
${ }^{2}$ Faísca and Lopes (2015) are the first since to have introduced a modern approach to this field.

3 This obliges us to incorporate two data sets which are constructed differently: the décima tax and the serviço tax of 1565, of which more below. The latter was also used by Johnson (2002).

4 The technical reasons are given in Cowell (2011). Only a few historical inequality studies have employed Theil indices among them Morrisson and Snyder (2000), Santiago-Caballero (2011) and Nicolini and Ramos-Palencia (2011). None of them has used this metric, however, in order to estimate a national index of inequality from a limited collection of data, like here.

5 To permit comparisons with the results of other researchers, below (Table 3) we display the scores for local inequality estimates both as Ginis and Theils.

6 For a non-Portuguese example of social table-based research, see Williamson (2009). For probate-based studies, see Cosgel and Ergene (2012) and Canbakal and Filiztekin (2013).
} 
been found for any year prior to $1800 .^{7}$ Probate inventories are not scarce, but have been rarely employed in research, and their dispersion makes them hard to handle. ${ }^{8}$ The only practical alternative is to resort to the rolls of taxpayers respecting income or wealth. Fortunately these are not only reasonably abundant but also the best suited for our objective.

A tax on the total net income of all households only came into force in Portugal in 1641 under the name of Décima de Guerra (or décima, for short). It can therefore only serve as a proxy for constructing the 1700 and 1770 benchmarks. Notwithstanding, its advantages for the present analysis are considerable. ${ }^{9}$ To begin with, it was annual and a universal imposition from which neither the nobility nor the magistracy nor the clergy was exempted. ${ }^{10}$ Secondly, it proxies one variable alone-income-and is therefore not contaminated by others, such as wealth or rent. In the third place, valuations were seriously intended to reflect solely the ability of each person to contribute and ignored other attributes that are common in early modern appraisals, like 'condition, power or honour' (Hanus 2013). Indeed, the royal edicts defining how fiscal appraisals should be made never failed to insist that evaluators 'keep justice and equity' and 'be especially careful in judging the commercial, business and manufacturing activity of each subject' (Oliveira 1971, vol. 1: 308). Finally, the décima was not farmed but administered by the crown, albeit with the help of local officials. As a result, much documentation has survived and the procedures are nationally homogenous because subjected to hierarchical supervision by royally appointed officials.

The décima was part of the effort to finance the war of independence from Spain between 1640 and 1668 , but ultimately lasted into the nineteenth century. ${ }^{11}$ It was due to all forms of personal income: rents from real estate; profits from business, trade, manufacturing and agriculture; income from all kinds of labour; and interest

\footnotetext{
7 The earliest known social tables are for the nineteenth century and are, respectively, in Franzini (1843) and Costa (1851).

${ }^{8}$ To date few monographs have relied on probate inventories: examples are an eighteenth century urban credit study and others concerning nineteenth century landed elites. See Rocha $(1991,1996)$ and Fonseca (1996).

9 The legislation on this tax is copious and conveniently compiled in the site http://www.juslusitaniae. fcsh.unl.pt. In the second half of the eighteenth century, the revenue from it amounted to 11 per cent of total state income (Costa et al. 2016: 219). The tax rolls used in the present study have been collected, for the décima, from the municipal archives of the localities to which they relate. The remaining ones are in print and can be found in: Lisbon-1565 (Livro 1947-8); Coimbra-1565, 1599 and 1613 (Oliveira 1971), Loulé-1564 (Magalhães 1970) and Tavira-1699 (Magalhães 1993).

10 The exclusion of religious corporations, i.e., regular clergy, from our assessment data does not necessarily imply any underestimate since it would be the equivalent to not including state corporations in the calculation of inequality in modern times. The church held out for an exemption of all its members, including the secular clergy, until the $1760 \mathrm{~s}$, and paid lump sums at times but ultimately had to give in. See Conde (2002/3). Individual priests, however, are regularly found in all periods on the rolls of tax payers. In some localities, beggars and others were shown to have no income at all. In such cases, given that they must have gained a 'survival income', we have attributed to them one half of the lowest earnings from labour shown in the tax roll. According to Tracy (2015: 515), in Europe, from the sixteenth century on, 'hitherto exempt clergy and nobles were now for the first time subjected' to these impositions.
}

11 There is no major history of Portuguese public finance during the Ancien Regime. Specifically on the décima, see Silva (1987), Magalhães (2004) and Costa (2009). 
on loans. In each household, the tax fell on the global net proceeds of as many of these activities as engaged its members. In the assessment rolls, these different components are presented separately and totalled under the name of the head of household. Initially, the rate was a flat, universal 10 per cent of net income. After 1668 , it varied between $4.5 \%$, in times of peace, and $10 \%$, in times of war or of the threat thereof. ${ }^{12}$

Prior to 1640 , direct taxes were raised by Portuguese monarchs at irregular intervals on the income or wealth of the population and subject to the approval of the Cortes (parliament). These were extraordinary measures for specific purposeswar, national celebrations, princely dowries or fiscal consolidation. ${ }^{13}$ Since the middle ages, they had been a common feature of fiscal Europe and were generally charged to heads of households on the basis of their economic capacity to pay. They might apply to the entire nation, or parts of it, according to their purpose.

The 'Tax for the Service of His Majesty' was one of these earlier forms of direct levy. It was exacted in 1565 and is employed here to enable us to extend the temporal range of our study back into the sixteenth century. It was a one-off exercise aimed at obtaining from the country the considerable sum of 40 million reais. It was applied throughout Portugal using administrative procedures that were very similar to those later employed when the décima was introduced. ${ }^{14}$ It was charged to each household at a flat rate of $0.7 \%$ of the value of the abode, irrespective of whether the property was rented or owner-occupied. It thus yields indirectly an estimation of the rental value of all residences and is therefore a source for the distribution of rents. In keeping with other recent early modern studies, we assume it is a reasonable guide for the household income distribution of the places observed (van Zanden 1995; Ryckbosch 2016; Alfani and Ammannati 2016; Hanus 2013).

At the top of the scale, there was a cap of one million reais on what a real estate owner would have to pay but all properties had to be valued first and therefore none should be absent from the listing. At the bottom, all living quarters with rental values below 2300 reais a year, whatever their resident's income or form of employment, were made to pay a fixed sixteen reais. Various privileged social groups were exempted in full: members of the court nobility, their fathers and grandfathers; the regular clergy; high magistrates; knights, their widows and their orphans; doctors in theology; and surgeons (Rodrigues 1970: 100). In the aggregate, these dispositions involved a downward bias since they would flatten the distribution both at the top and at the bottom of the register.

How reliable are these taxes for studying economic inequality in this period? Certainly there were selection biases in both sources. Some of them were expressly built into the design of the tax system, e.g., exemptions for certain social classes. Others were the result of individual efforts to evade fiscal obligations altogether or

\footnotetext{
12 The exact chronology of these oscillations can be found in http://www.iuslusitaniae.fcsh.unl.pt/.

13 The exaction of such levies by the Portuguese kings has been little explored by economic historians. See, however, Gonçalves (1964) and Dominguez (2015).

14 The 1565 tax rolls are a well-known source for historians. They have been used by Rodrigues (1970), Magalhães (1970) and Oliveira (1971). The full text of the Lisbon tax roll has been transcribed in Livro (1947-8), which also contains the royal edict specifying the rules for its application.
} 
to reduce the value of family appraisals by falsifying documents and distorting declarations. Obviously, the difficulty in determining the magnitude of these deviations is considerable. Some checks on them are possible, however.

Collective tax exemptions would have had the greatest distortive impact on the assessment schedules. After all, they usually affected social groups at the two ends of the distribution. In the case of the rich, they represented a large share of total income. With the poor, it was not their share of income that made the difference to inequality, but their large numbers. In the case of the Lisbon Serviço tax, the two lowest income classes - the 'braceiros' (unskilled manual workers) and 'others' together constituted $39.1 \%$ of all the potential taxpayers in the city (Rodrigues 1968: 150). Thus, in a system which taxed wealth and therefore excluded such people from payment, this would have meant a significant reduction in the inequality estimate. $^{15}$

A suggestive yardstick for gauging the distortions caused by exemption and evasion is the gap between two variables: the total number of households in a locality - the potential capacity of the fiscal system-and that of those actually assessed. It is displayed in Table 1, which shows the ratio between these two magnitudes, along with the time and place of each observation, in the few years when satisfactory data could be gathered. This is not a perfect indicator because it compares two counts of different qualities: a frequent household one by tax officials and a very occasional one, simply of abodes, carried out with haphazard methods. Table 1 therefore only comprises urban locations since the unreliability of rural population tallies is difficult to check. Two significant findings emerge nevertheless. Firstly, avoiding personal taxes does not seem to have been all that easy. Though the ratio has some variance, it is remarkable how often and how close the size of the two communities could be. Secondly, the serviço tax was clearly less effective than the décima, given its exemptions, and biased results towards a lower-bound estimate of inequality. ${ }^{16}$ This demonstrates the superiority, in terms of accuracy of results, of a system like the décima over any real estate or wealth-based method of taxation such as were common in Europe at this time.

Trying now to judge distortions caused by individual prevaricators is a lot more challenging and probably quite unfeasible by any direct approach. A different way is to consider the mechanisms used to assess income tax liability and thus appraise, impressionistically, how easy it would have been to elude them. Several features of the décima methodology were notably well designed to dissuade shirking. One aspect was the already noted countrywide homogeneity of direct tax regulation which stopped cheats from sheltering under excessive regulatory complexity. ${ }^{17}$ Another was to make the lists of taxpayers in each

\footnotetext{
15 Examples of situations where significant segments of the population were left out of the tax rolls, and the implications arising from this are found in Piedmont and Florence (Alfani 2015; Alfani and Ammannati 2016); and the Netherlands (Van Zanden 1995; McCants 2007).

16 Faísca and Lopes (2015) corroborate this finding for three localities (Arraiolos, Avis and Portalegre) in the province of Alentejo for the early eighteenth century.

17 Morrisson and Snyder (2000) and Santiago-Caballero (2011) show how in the course of time a simple set of fiscal arrangements could be transformed into a cumbersome mosaic of fiscal localism, which soon became fossilized.
} 
Table 1 Urban households: inhabited versus assessed. Sources: The assessment dates are those in the tax records, see Table 3; for the number of taxed houses, same source; for the number of total households see Johnson (2002) for 1565; Costa (1708) for 1690, 1698, 1699 and 1725; and for all late eighteenth-century dates, Memórias Paroquiais, 1758, in Portuguese National Archives

\begin{tabular}{llcrc}
\hline Locality & Date of assessment & Taxed households & Total households & Share taxed \\
\hline Lisboa & 1565 & 15,025 & 18,000 & 0.83 \\
Loulé & 1565 & 694 & 691 & 1.00 \\
Portalegre & 1725 & 1488 & 1530 & 0.97 \\
Avis & 1690 & 568 & 600 & 0.95 \\
Vila do Conde & 1698 & 714 & 750 & 0.95 \\
Castro Marim & 1699 & 482 & 600 & 0.80 \\
Guarda & $1763 / 1769$ & 820 & 743 & 1.10 \\
Viseu & 1763 & 469 & 529 & 0.89 \\
Caminha & 1767 & 325 & 335 & 0.97 \\
Vila do Conde & 1763 & 706 & 869 & 0.81 \\
\hline
\end{tabular}

locality coincide with those of parishioners drawn up by local priests in order to monitor the fulfilment of religious duties. Thirdly, conjoining names and residences rendered this compilation effort a highly effective instrument for keeping track of all the other pieces of information needed for estimating individual fiscal capacity.

The construction of the décima database fell to four local wise men appointed by the municipal council. For each street, two assessors, who were residents in it and would counter-check each other, were chosen by them to draw up the respective list of householders, which is to say, of taxpayers. They were expected to be familiar with the affairs of its inhabitants, in particular their income and possessions. This operation was overseen by a magistrate without local ties, who was directly appointed by the crown. A further control was to ensure that assembling taxpayer lists followed a rigorous geographic criterion. In urban centres, it was done streetby-street and house-by-house. In the countryside, it was done hamlet-by-hamlet or farm-by-farm. In either case, the lists were systematically compared with earlier ones and any gap in the tally had to be justified. As a result, concealing a taxpayer's 'absence' or justifying an erroneous appraisal of his means, which tended to be known to many, could be risky. ${ }^{18}$

Even if it was hard to 'disappear' from the rolls, did the rich manage to transfer the fiscal burden onto the shoulders of the poor by tampering with or underreporting their assessments? Was this on a scale sufficient to make a difference to a broad measure of inequality? A simple test is to plot income inequality profiles, i.e., the cumulative frequency of individual incomes, at different times and in different

\footnotetext{
18 The Regimento da Décima of 1654 prescribed the following steps for compiling a tax roll: (1) start with the list of parishioners, and call them in one by one to describe their employment, assets and income (2) verify this information by questioning other people (3) walk up and down the street to check the names of the residents and see whether any are missing or whether there are any new ones (4) calculate the assessments and write them into two copies of the roll, one to be kept locally and the other to be sent to Lisbon. See http://www.juslusitaniae.fcsh.unl.pt.
} 


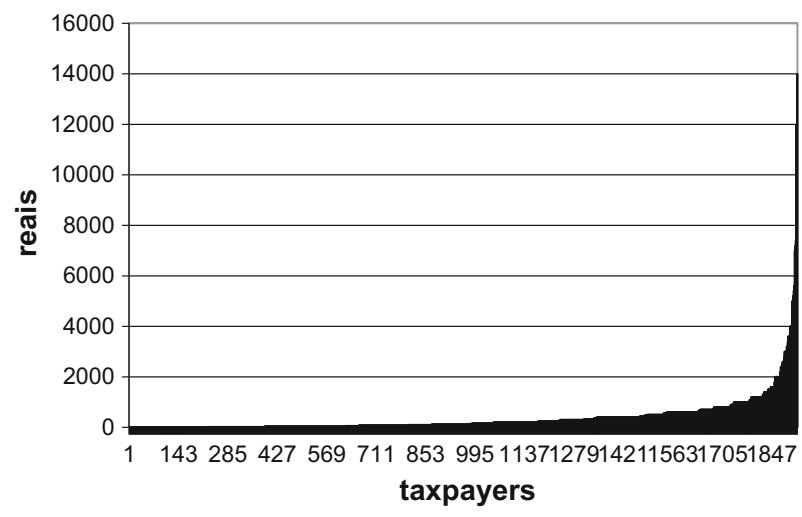

Fig. 1 Cumulative income distribution, Coimbra, 1567. Sources: see text and Table 3

Fig. 2 Cumulative income distribution, Caminha 1767. Sources: see text and Table 3

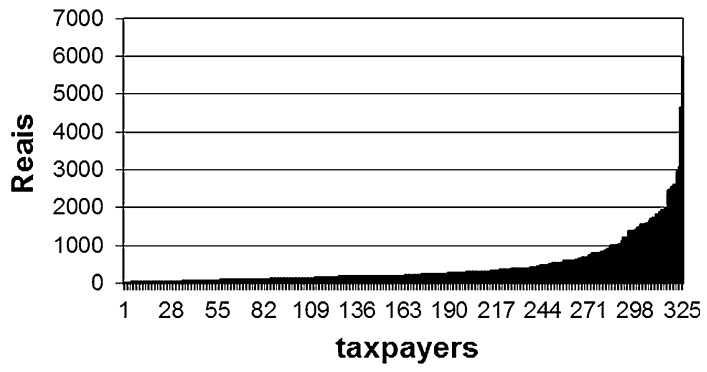

parts of the country. ${ }^{19}$ To some extent at least this should reveal whether there was an excessive accumulation of income at the bottom of the distribution, or too little of it at the top, thus contributing artificially to the high inequality counts which we obtain in the next section. Figures 1 and 2 provide examples, namely the towns of Coimbra and Caminha, respectively, in the sixteenth and eighteenth centuries. The impression given by these two histograms does not diverge from expectation: a long tail of very poor taxpayers and a short one with a high concentration of wealth or income in the hands of a tiny share of well off households at the other extreme. ${ }^{20}$

\section{Estimates of income distribution for Portugal}

In this section, we estimate a consistent national income inequality index for Portugal over a significant part of the Early Modern period. The strategy is to construct a Theil index $[\mathrm{GE}(1)]$ for each of our benchmark years. We thereby take

\footnotetext{
19 Another, more elaborate method would have involved examining how income was spread out over the different deciles of the distribution. This is done by Faísca and Lopes (2015) for a small sample of localities and corroborates our graphic findings.

20 Additional histograms for other localities can be obtained on request from the author. For a similar situation regarding Naples in 1811, see Malanima (2006).
} 
advantage of the decomposability of this metric but use it inversely to the usual procedure. Thus, rather than start from an existing national estimate of inequality and decompose it into sub-indices of inequality, we follow a bottom-up 'additive strategy'. This involves grossing up to a national Theil from a collection of Theil indices corresponding to the different settlement types of the country and weighted by their respective populations and per capita incomes. The expression used is

$$
T=\sum(\mathrm{Nj} / N) *(\mathrm{Mj} / M) * \mathrm{Tj}+\sum(\mathrm{Nj} / N) *(\mathrm{Mj} / M) * \ln (\mathrm{Mj} / M)
$$

in which $\mathrm{T}$ and $\mathrm{Tj}$ are the national and the local settlement Theils, respectively; $\mathrm{Nj}$ and $N$ are 'local' and national tax-paying population sizes measured by the number of households, respectively; $\mathrm{Mj}$ and $M$ are the respective mean incomes per household at the settlement and national levels (Sala-i-Martin 2002; Steckel and Moehling 2001). The last of these is proxied by the tax assessment per household.

Before estimating our results, certain preliminaries need to be worked out. The first is to develop a grid of population settlement types that capture their distinctive time-invariant characteristics with regard to economic inequality. This is a central assumption for structuring this paper. It is inspired by the welter of early modern local, micro-studies that show stable relations between local inequality, on the one hand, and a combination of community sizes and economic specializations on the other hand. Thus, for centuries, rural inequality in Europe tended to be significantly lower than urban. Within urban communities, their size tended to be positively correlated with disparity in income or wealth. In eighteenth century Spain, for example, the larger villages in rural Guadalajara were more unequal than the smaller ones (Santiago-Caballero 2011). While in Madrid the Gini for income was 0.77 , in Jerez de la Frontera, a small peripheral town, it was 0.50 (Alvarez-Nogal and Prados de la Escosura 2007). An additional distinction is present in the Dutch province of Overijssel in 1750, where prospering towns showed a higher degree of inequality than did stagnant ones of similar scale. As Van Zanden (1995: 649) observed, 'economic development, urbanization and capital accumulation in the early modern period went hand in hand with an increase in inequality'.

In this perspective, in Table 2, we use the following four categories: the two main cities, that is, the capital (Lisbon) and Porto; the urban centres with more than 1000 households; smaller towns than these, with less than 1000 households; and the countryside proper. $^{21}$ This enables us to display the total population and the population shares of these categories at each benchmark and thus supply the values for $\mathrm{Nj}$ and $\mathrm{N}$ required for expression (1) above.

A second preparatory step organizes the data of all localities and displays them in Table 3. This comes to a total of twenty-seven cases, including three which are not from archival records but inferred indirectly from other sources. Aside from their respective income Ginis and Theils (the former for the sake of comparing with studies which do not use Theils), the location and date of each record, the type of settlement and the number of households in each one are also shown. In addition, there is a set of dummies for urban centre, coastal town and

\footnotetext{
$\overline{21}$ Van Zanden (1995) follows a similar procedure but employs five categories instead.
} 
Table 2 Population and shares of national population by four types of settlement (1000s of inhabitants). Sources: Bairoch et al. (1988) and Palma and Reis (2016)

\begin{tabular}{lrrrrrr}
\hline & \multicolumn{1}{c}{1565} & \multicolumn{1}{c}{$\%$} & \multicolumn{1}{c}{1700} & \multicolumn{1}{c}{$\%$} & \multicolumn{1}{c}{1770} & \multicolumn{1}{c}{$\%$} \\
\hline Principal cities & 86.0 & 6.4 & 205.0 & 8.9 & 226.0 & 7.7 \\
Major towns & 94.0 & 6.9 & 123.5 & 5.4 & 264.0 & 9.1 \\
Minor towns & 45.0 & 3.4 & 70.5 & 3.1 & 56.0 & 1.9 \\
Countryside & 1125.0 & 83.3 & 1901.0 & 82.6 & 2366.0 & 81.3 \\
Total population & 1350.0 & 100.0 & 2300.0 & 100.0 & 2912.0 & 100.0 \\
\hline
\end{tabular}

Principal cities are Lisbon and Porto; major towns are all other urban centres with more than 1000 households; minor towns are those with less than 1000 households; the countryside is all non-urban population. Population is in 1000s of inhabitants

for seat of national government (Lisbon). As a proxy for per capita income-of critical importance for the Theil index-we use the weighted mean, within settlement types, of real household income assessments. The national mean for this variable is weighted by the respective number of taxed households in each place.

A third stage in the estimation process seeks to attest the reliability of these inputs. We start by noting that almost all our local observations are complete. They are the integral schedule of taxpayers in each locality considered, not a sample from it. ${ }^{22}$ We may thus suppose them to be reasonably representative of the distribution patterns associated with the respective standard settlements across the national spectrum at each of our benchmarks. Secondly, we consider the possibility of a geographic selection bias. The different localities we have collected in Table 3 encompass the most significant regional contrasts to have shaped Portuguese social and economic history during these centuries. The oppositions in question are those relating to minifundiary versus latifundiary agro-systems, coastal plains versus hilly interior, pastoralism versus grain production, and shipping and fishing versus rural communities (Ribeiro 1986).

A further worry is that our data should be plausible in the light of historical knowledge about early modern Europe, a major feature of which was a marked high level of inequality compared to present-day standards (McCants 2007). This concern is readily dispelled by noting the high level of Ginis to be found in Table 3 irrespective of time and place. Out of twenty-four, four were less than 0.5. Of the remaining twenty, sixteen were between 0.5 and 0.7 , and four were above $0.7 .^{23}$ Another is the descending pattern of inequality relative to the degree of development of settlements in Portugal at each benchmark from the sixteenth century onwards. Figure 3 reveals a consistent pattern of the highest Ginis occurring in principal cities, then falling with the passage to major and then to lesser towns,

\footnotetext{
${ }^{22}$ To arrive at this, we have discarded a number of unsatisfactory tax rolls employed by Johnson (2002). The main reasons were either a large numbers of fiscal exemptions and exclusions in some pre-décima lists, or a lack of access to the original lists of individual taxpayers. Often Johnson presents the data in an aggregated form. Owing to difficulties in sampling the national décima pool, the contents of which are widely spread across the country, we chose the localities to which we had easier access.

${ }^{23}$ For four entries, data were unavailable for calculating Ginis.
} 
Table 3 Inequality indices and summary statistics of localities: 1565, 1700, and 1770. Sources: for population, Bairoch et al. (1988); for CPI ('respectable') and GDP per capita, see Palma and Reis (2016); for other data, see text

\begin{tabular}{|c|c|c|c|c|c|c|c|c|c|c|}
\hline Locality & Date & $\begin{array}{l}\text { CPI } \\
\text { 'respectable' }\end{array}$ & $\begin{array}{l}\text { Real } \\
\text { GDP } \\
\text { pc }\end{array}$ & $\begin{array}{l}\text { Total } \\
\mathrm{HH}\end{array}$ & $\begin{array}{l}\text { Real } \\
\text { tax per } \\
\mathrm{HH}\end{array}$ & UR & Gini & Theil & Port & Govt \\
\hline Lisboa & 1565 & 100 & 112 & 15,014 & 365 & 1 & 0.802 & 1.448 & 1 & 1 \\
\hline Porto* & 1565 & 100 & 112 & $3500 *$ & $365^{*}$ & 1 & - & $0.838 *$ & 1 & 0 \\
\hline Coimbra & 1567 & 100 & 112 & 1920 & 390 & 1 & 0.692 & 0.990 & 0 & 0 \\
\hline Loulé & 1564 & 100 & 112 & 694 & 43 & 1 & 0.714 & 1.127 & 0 & 0 \\
\hline Loulé & 1564 & 100 & 112 & 507 & 23 & 0 & 0.553 & 0.538 & 0 & 0 \\
\hline Coimbra & 1599 & 100 & 115 & 1334 & 118 & 1 & 0.696 & 1.178 & 0 & 0 \\
\hline Coimbra & 1613 & 100 & 115 & 1599 & 427 & 1 & 0.698 & 1.165 & 0 & 0 \\
\hline Avis & 1690 & 95 & 121 & 311 & 636 & 1 & 0.656 & 0.829 & 0 & 0 \\
\hline Avis & 1690 & 95 & 121 & 313 & 1321 & 0 & 0.636 & 0.791 & 0 & 0 \\
\hline $\begin{array}{l}\text { Vila do } \\
\text { Conde }\end{array}$ & 1698 & 95 & 121 & 714 & 305 & 1 & 0.583 & 0.697 & 1 & 0 \\
\hline Tavira & 1699 & 95 & 121 & 446 & 1139 & 1 & 0.576 & 0.672 & 1 & 0 \\
\hline Arraiolos & 1700 & 95 & 121 & 552 & 456 & 1 & 0.650 & 0.925 & 0 & 0 \\
\hline Arraiolos & 1700 & 95 & 121 & 374 & 809 & 0 & 0.650 & 0.760 & 0 & 0 \\
\hline Porto & 1700 & 95 & 121 & 6000 & 263 & 1 & 0.667 & 1.022 & 1 & 0 \\
\hline Lisbon* & 1700 & 95 & 121 & 45,000 & $263^{*}$ & 1 & - & $2.901 *$ & 1 & 1 \\
\hline Portalegre & 1725 & 110 & 150 & 1279 & 129 & 1 & 0.497 & 0.743 & 0 & 0 \\
\hline Portalegre & 1725 & 110 & 150 & 682 & 72 & 0 & 0.472 & 0.499 & 0 & 0 \\
\hline Galveias & 1753 & 106 & 161 & 161 & 145 & 1 & 0.636 & 0.794 & 0 & 0 \\
\hline Galveias & 1753 & 106 & 161 & 107 & 2635 & 0 & 0.610 & 0.750 & 0 & 0 \\
\hline Guarda & 1766 & 119 & 151 & 1042 & 617 & 1 & 0.744 & 1.362 & 0 & 0 \\
\hline Viseu & 1763 & 119 & 151 & 469 & 96 & 1 & 0.696 & 1.018 & 0 & 0 \\
\hline Caminha & 1767 & 119 & 151 & 2027 & 40 & 0 & 0.483 & 0.401 & 1 & 0 \\
\hline Caminha & 1767 & 119 & 151 & 325 & 39 & 1 & 0.585 & 0.753 & 1 & 0 \\
\hline $\begin{array}{l}\text { Vila do } \\
\text { Conde }\end{array}$ & 1763 & 119 & 151 & 706 & 596 & 1 & 0.559 & 0.663 & 1 & 0 \\
\hline $\begin{array}{l}\text { Vila do } \\
\text { Conde }\end{array}$ & 1763 & 119 & 151 & 125 & 532 & 0 & 0.450 & 0.320 & 0 & 0 \\
\hline Porto & 1776 & 121 & 150 & 9000 & 1274 & 1 & 0.700 & 1.032 & 1 & 0 \\
\hline Lisbon* & 1776 & 121 & 150 & 47,500 & $1274^{*}$ & 1 & - & $3.099 *$ & 1 & 1 \\
\hline
\end{tabular}

HH-households (1000s); UR dummy (urban =1); port dummy (coastal town dummy = 1); Govt dummy (seat of government $=1$ ). Interpolated data for inequality are marked with an asterisk

and, finally, to rural communities, as the lowest. In this optic, Portugal was certainly not an outlier.

Unfortunately, our data set has three troublesome gaps in it. For lack of certain tax assessment rolls, we are unable to estimate Theils for Porto in 1565, Lisbon in 1700 and Lisbon in 1770. Given their economic and demographic centrality, it is important to fill them in. The missing information is interpolated by means of an 


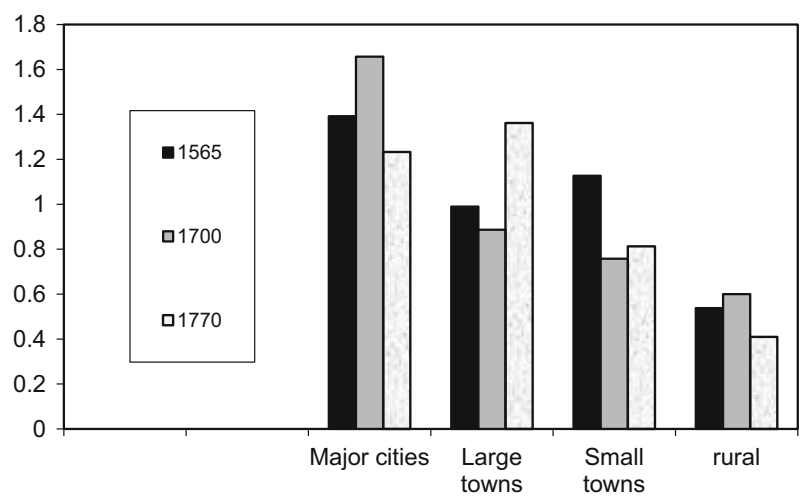

Fig. 3 Local inequality in Portugal, 1565-1770 (Theil). Sources: Tables 2 and 3

OLS regression model. In it, the index of inequality is the dependent variable and the independent variables represent the main determinants of inequality as suggested by the literature. ${ }^{24}$ The expression used is

$$
T=a+b * \mathrm{HH}+c * \mathrm{UR}+d * \operatorname{Port}+e * \mathrm{Tax}+\varepsilon^{\varepsilon}
$$

in which $\mathrm{T}$ is the Theil coefficient for a given locality and date, $\mathrm{HH}$ is the number of households in it which were assessed, UR is a dummy for towns or cities $(=1)$, Port is a dummy for a port city $(=1)$, Govt is a dummy for the seat of government (Port $=1)$, and Tax is the real value of the assessment per household. The error term is $\varepsilon$.

The regression is run without logs, and its output is displayed in Table 4. This shows a satisfactory fit as well as highly significant coefficients for most of the independent variables, despite a limited number of degrees of freedom. We are able to conclude from it that the size of the locality, whether or not it was urban or coastal, and the amount of tax due per household all raised inequality. Using the estimated coefficients, we reckon indirectly but with reasonable accuracy the missing 'local' Theils in Table 3. We are thus able to obtain a less biased result for the final estimation of the national inequality index than would have been possible otherwise.

With the evidential picture now complete, we move on to calculate, by means of the 'short-cut' methodology described in (1), the values of the Theil index for Portugal in 1565, 1700 and 1770. The outcome is displayed in Table 5. As noted, these estimates are subject to a number of caveats connected with the quality of the data and the methods employed for their collection, as well as by the assumptions required in order to carry out our research strategy.

The path of income inequality between 1565 and 1700 indicated by these figures is a fairly steep downward sloping line. It is followed by a gentler upward gradient in the ensuing seven decades, which does not restore, however, the level of

\footnotetext{
${ }^{24}$ Three recent studies have used this strategy with success, both to fill in information gaps, as we do here, and in order to model the factors which determine inequality. We use their explanatory variables. See Malanima (2006); Williamson (2009); and Ryckbosch (2016).
} 
Table 4 Determinants of the Theil index. Source: Table 3 without interpolated data
$\mathrm{HH}=$ total households (1000s); urban = urban dummy (town/ city $=1$ ); port dummy (coastal town/city =1); Govt dummy (Lisbon $=1$ ); real tax per $\mathrm{HH}=$ real per household tax; real GDP pc $=$ real gross domestic product per capita

\begin{tabular}{|c|c|c|c|}
\hline \multicolumn{4}{|l|}{ Linear regressions (OLS) } \\
\hline \multicolumn{4}{|c|}{ Dependent variable: local (Theil) income inequality index } \\
\hline Indep. variables & Coef. & Coef. & Coef. \\
\hline Constant & $\begin{array}{l}0.7724 * * * \\
(0.0583)\end{array}$ & $\begin{array}{l}0.5372 * * * \\
(0.0673)\end{array}$ & $\begin{array}{l}0.8362 * * * \\
(0.2727)\end{array}$ \\
\hline $\mathrm{HH} / 1000$ & $\begin{array}{l}0.0424 * * * \\
(6.15 \mathrm{e}-03)\end{array}$ & $\begin{array}{l}0.0499 * * * \\
(5.32 \mathrm{e}-03)\end{array}$ & $\begin{array}{l}0.0427 * * * \\
(0.0121)\end{array}$ \\
\hline Urban & - & $\begin{array}{l}0.4009 * * * \\
(0.0767)\end{array}$ & $\begin{array}{l}0.3936^{* * *} \\
(0.0823)\end{array}$ \\
\hline Port & - & $\begin{array}{l}-0.3019 * * * \\
(6122)\end{array}$ & $\begin{array}{l}-0.2791 * * * \\
(0.0795)\end{array}$ \\
\hline Govt & - & - & $\begin{array}{l}0.0750 \\
(0.1458)\end{array}$ \\
\hline Real tax per $1000 \mathrm{HH}$ & - & $\begin{array}{l}0.725 * * \\
(0.0346)\end{array}$ & $\begin{array}{l}0.0853 * * \\
(0.0039)\end{array}$ \\
\hline Real GDP per capita & - & - & $\begin{array}{l}-0.0022 \\
-(0.0021)\end{array}$ \\
\hline $\mathrm{N}$ & 24 & 24 & 24 \\
\hline$R^{2}$ & 0.265 & 0.744 & 0.764 \\
\hline Prob $>F$ & 0.000 & 0.000 & 0.000 \\
\hline
\end{tabular}

Table 5 Estimated income inequality for Portugal, 1565-1770 (Theil index). Sources: see Table 3 and text

\begin{tabular}{llll}
\hline Benchmark & Total inequality & Within groups & Between groups \\
\hline 1565 & 1.336 & 0.797 & 0.539 \\
1700 & 0.775 & 0.737 & 0.039 \\
1770 & 0.978 & 0.919 & 0.058 \\
\hline
\end{tabular}

inequality at the starting point. In the present state of the art, these estimates are interesting in several ways. The first is that, in terms of early modern European history, this is quite a lengthy time span (1550-1770) for a national estimate to cover. ${ }^{25}$ The second is that it is mainly based on direct evidence on income, an unusual situation. The third is that it discloses a case, rare in Europe, of a protracted decline in income inequality during a time when the opposite was the norm. Although the trend was not persistently of decline, nevertheless, in the course of the two hundred and twenty years shown here, it demonstrated no tendency to recover anything like the high disparity level which had characterized the late fifteen hundreds.

\footnotetext{
${ }^{25}$ Morrisson (2000) includes several national studies covering significant time spans, but they are shorter and encompass mainly the period of industrialisation. However, a few have covered similar or longer intervals-Alfani (2015); Ryckbosch (2016); Van Zanden (1995).
} 


\section{Why did early modern Portugal become more equal?}

In the pre-industrial history of income distribution, Portugal represents a singular case. For over two hundred years, its permanent decline in inequality stands in stark contrast with the rise in this parameter in the many other countries which have been submitted to similar scrutiny. Consistently, the general view on the latter has been that 'during the early modern period, inequality grew everywhere' (Alfani 2015: $2)^{26}$ The question this poses is whether Portugal simply reacted differently to the same forces present in other countries, or, instead, responded 'normally' but to different forces. In these final pages, we try and show that the correct answer was largely the second of these alternatives.

The new literature on early modern inequality, to which this article belongs, has tried to establish a unified explanation that would account for all national income and wealth disparities and their variation. Its principal goal has been to set up causal frameworks that will fit together a variety of distributional outcomes with the specific circumstances of each place and moment. A legacy has gradually emerged from this collective effort at theorizing inequality and can by now be summed up in a set of four propositions.

The first one was suggested by Kuznets in a celebrated article in $1955 .{ }^{27}$ The proposal was that when an economy started to undergo 'modern economic growth', output per capita rose and labour productivity increased and spread out differentially across the board. The work force shared in these gains differentially too and experienced compositional shifts which together originated the income disparities that we are seeking to explain. In early modern economies, on the other hand, not much of this dynamism was displayed. In the very few 'core' ones that did, however, one may come across a positive, stable relationship between income inequality and variation in economic structure and GDP per capita, as Van Zanden (1995) maintained he did in Holland and later in Britain.

The second-a so-called Williamson effect ${ }^{28}$ - concerns a state of development in which a rising demand for skills and qualifications results from a sustained process of economic growth and development. A share of the labour force should end up in receipt of ever-rising premia on this account, as the production of the desired amount of human capital is continually challenged by the skill scarcities induced by the pace of economic transformation. In this case, the effect of economic inequality shifts would be concentrated at the level of the labour force and be closely dependent on human capital production.

The third hypothesis has its lineage in the 'classical economists'. It claims that what drove distributional alterations were supervening modifications in the

\footnotetext{
${ }^{26}$ Practically every study in this field has concluded in a similar vein. Hoffman et al. (2002) find that: 'inequality within the nations of western Europe has risen greatly' (p. 324). This is echoed by Van Zanden (1995): 'a super Kuznets curve spanning many centuries [...] was characterized by rising inequality' (p. 662). Ryckbosch (2016: 1) speaks of 'a clear growth in economic inequality in the two centuries prior to the industrial revolution'.

${ }^{27}$ Kuznets (1955). The present description of these four hypotheses can be followed in two excellent summaries by Van Zanden (1995) and Ryckbosch (2016).

${ }^{28}$ Invoked by Van Zanden (1995) and Ryckbosch (2016).
} 
functional distribution of income, i.e., how output was shared between the factors of production (Ryckbosch 2016). The question then becomes-what propelled these modifications? The starting point was an original, stable combination of production factors, the division of which had then to evolve in response to readjustments over time in the original relation between them. In some situations, this re-distributional exercise was driven by 'the power and position of the various social groups', i.e., landowners or capitalists, to the detriment of labour (Van Zanden 1995: 661). In other, more advanced, capitalised economies such imbalances were propelled by the acceleration of urban capital accumulation in the hands of a few. In the majority of cases, it was the result of Malthusian population pressures, which led to a decline in the land-labour ratio. In the absence of technological shocks, a fall in labour productivity and real wages ensued and caused a mounting spread between the earnings accruing to land and those accruing to labour. Obviously, given the predominance in the economy of these two factors, the long-run implication of this scenario was a rise in economic inequality overall (Bértola et al. 2010).

Our fourth premise deals with the impact of institutions in the broadest sense. It is the one which takes us closest to considering exogenous factors as determinants of long-run income disparities. It is also the one which is hardest to handle in terms of quantification and the exact specification of the variables considered. It has nevertheless been usefully invoked by several studies (Van Zanden 1995; Milanovic et al. 2011; Alfani 2015) even if, for the time being, its implementation has tended to be of a residual and speculative nature.

To establish which of these forces provides the best interpretation for the longrun change in Portugal's distribution, we need first to sketch the relevant features of its early modern economy. Recent research based on an extensive new database rejects the traditional image of a stagnant and impoverished country (Palma and Reis 2016). Instead, it documents intensive growth between 1550 and 1750, in the course of which real GDP per capita almost doubled. This was supported essentially by the primary sector, though after 1700 also by burgeoning gains from colonial exploitation. Two major technical changes in agriculture were decisive. One was the largest 'maize revolution' in Europe from the early 1600s, which replaced to a large extent the production and consumption of wheat and rye by this far more effective crop. The other was the rise, from the late $1600 \mathrm{~s}$, of an export-oriented high-quality wine sector with a virtual monopoly in the buoyant British market until late in the eighteenth century. Both were highly labour-intensive, which led to a significant 'agro-industrious revolution'-between 1600 and 1800 the supply of labour per capita increased by 50\% - though not to a profound re-structuring of the economy. In this respect, Portugal contrasted with what was meanwhile happening in the two economic leaders of Europe in the late early modern period (Broadberry et al. 2015; Van Zanden and Van Leuween 2012).

Thanks to freshly minted metrics, it is now feasible to test quantitatively our case study regarding the propositions outlined above. Given Portugal's quite vigorous long-term performance, we use three yardsticks to explore the first of the questions raised above. Figure 4 displays the shares of urban population and non-agricultural labour alongside our three inequality benchmarks. In a presumed situation of Kuznetsian labour shifts, from low-paid, 'traditional' occupations to better paid, 


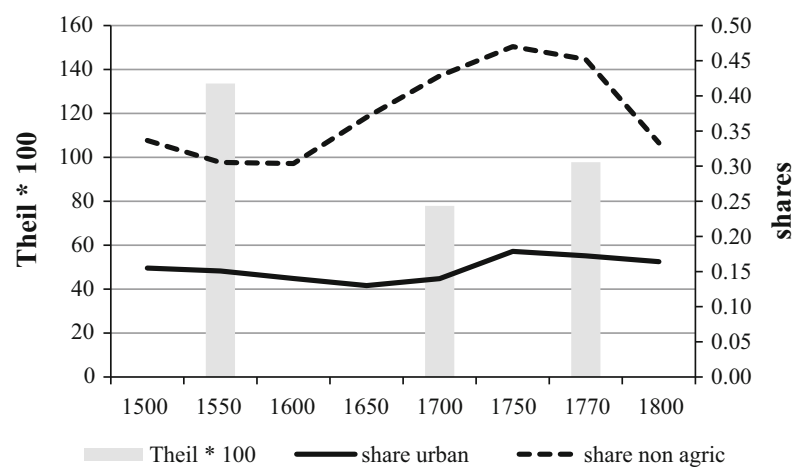

Fig. 4 Structural change: explaining Theil. Sources: Table 5; Palma and Reis (2016)

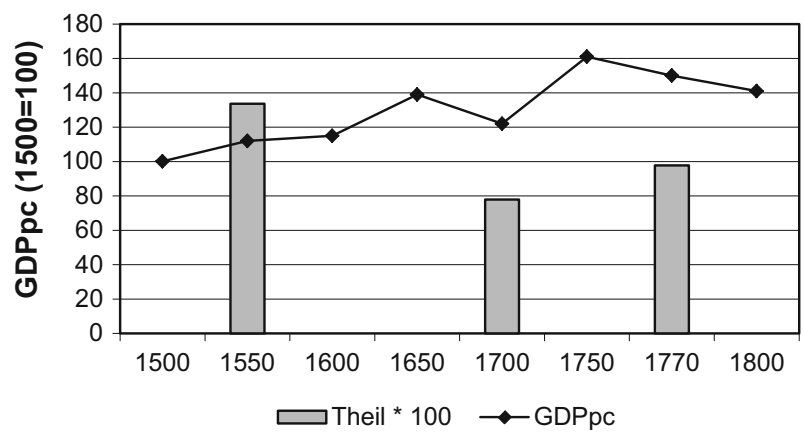

Fig. 5 Economic growth: explaining Theil. Sources: Table 5; Palma and Reis (2016)

'modern' sector jobs, the expectation would be that the first two variables should vary positively with changes in inequality. In fact, they did not. The urban population share did not vary at all until 1700 and only very little thereafter. At the same time, the non-agricultural labour-share marker also behaved in the opposite way to what one might suppose. The failure of the model is equally brought out by Fig. 5, which shows a persistent mismatch between per capita GDP and the inequality trend. A reasonable explanation for both explanatory difficulties is that in this epoch growth could occur, but often did not generate significant structural change and this rendered this kind of distributional impact less likely.

Harnessing a 'Williamson effect' to the present analysis may be expected to run into similar difficulties. Weak structural modifications would again be the principal cause. To verify this assertion, we make use of two more new indicators for Portugal-a ratio of skilled-to-unskilled wages and another comparing the salaries of non-manual, essentially urban occupations with the wages of manual unskilled workers. They are presented, respectively, in Figs. 6 and 7, and provide elucidation for our question. Over the long run, the highest paid and most skilled or qualified benefitted least from changes in demand for human capital attributes. ${ }^{29}$ Given the

\footnotetext{
29 In Holland and in particular the Dutch cities, the exact opposite occurred. See Van Zanden (1995).
} 


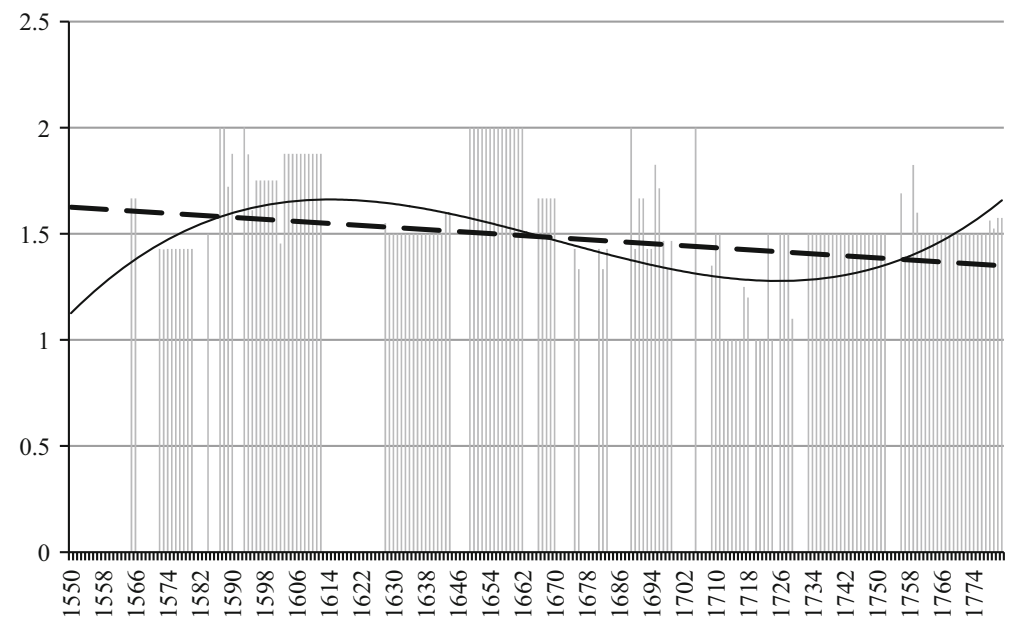

Fig. 6 Skilled-unskilled wage ratio. Source: Palma and Reis (2016)

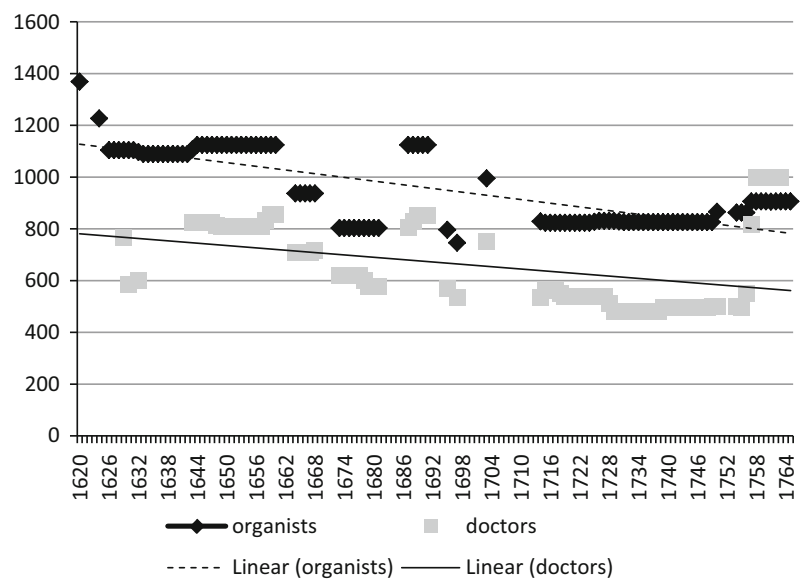

Fig. 7 Ratio of salaries of organists and doctors to unskilled wages. Sources: Palma and Reis (2016); PWR database

urban nature of these mid-range occupations and the slow rate of the country's urbanization, this should come as no surprise. The relative scarcity of mostly rural, raw labour on which we are basing our analysis kept its earnings at least abreast or even ahead of those of the qualified workers with better paid jobs which this society seemingly overproduced.

We now turn to shifts in the distribution of functional income, the most promising angle for the question this paper poses. The theoretical background is the Malthusian model. Here the prime features are 'relatively stagnant real wages and per capita output' and 'an increasing population [which] pressed on a quasi-fixed land endowment, to the benefit of landlords' (O'Rourke and Williamson 2005: 6). 


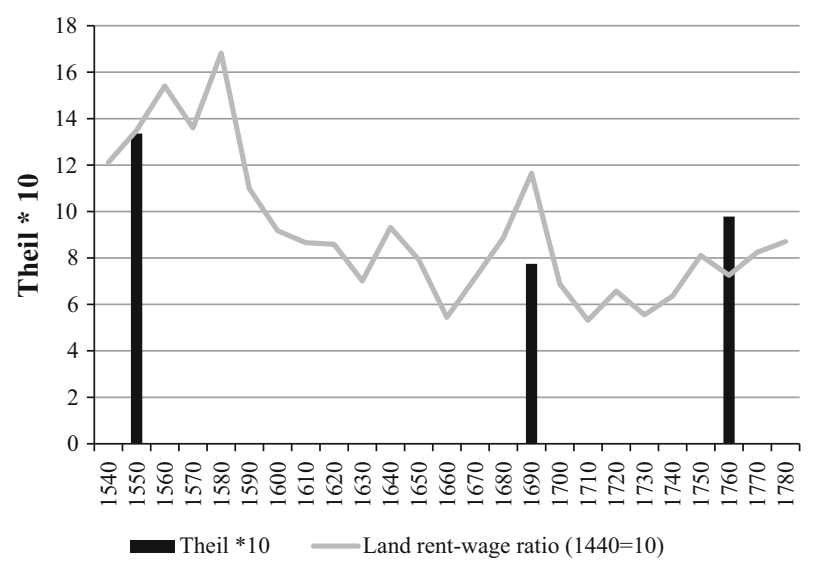

Fig. 8 Rent-wage ratio and inequality. Sources: Palma and Reis (2016) and Table 5

This has a considerable relevance for the topic of inequality. In an agrarian economy like Portugal's, where the majority lived off the land, a large share of national product accrued to the agricultural sector and was divided among cultivators and landholders. This division was determined principally by population pressure, which governed the size of the land-labour ratio, and by the evolution of the social and legal conditions that shaped access to natural resources. Combined, these were the crucial influences on the distribution of the nation's income.

In the canonical Malthusian model, a rising population like that of Portugal, and indeed Europe, would imply increasing land scarcity, a rising rent-wage ratio and escalating inequality. In fact, as Fig. 8 demonstrates, the trend was the opposite. A rising shortage of land - the land-labour ratio fell to half between 1550 and 1750was accompanied, at first sight strangely, by a falling rent-wage ratio and greater overall distributional equality, except for the end of the period when inequality picked up a little, in step with an increase in the rent-wage ratio. This is not, however, the paradox it might appear to be. The reason is the remarkable transformation of the primary sector towards a new and increasingly labourintensive agriculture, which was able therefore to absorb significantly larger amounts of labour and sustain a more equitable repartition of earnings. This is something that most contemporary economies were not able to do and consequently the reason why, in contrast with Portugal, they endured rising inequality.

Although indubitably of great importance, institutional factors have not yet established a strong analytic position in the dispute over the determinants of national income inequality profiles. The key concept here is extractiveness, a capacity displayed by the state or by powerful groups protected by it, to obtain additional income for themselves by means other than market forces (Milanovic et al. 2011). In research on early modern Portugal, this problematic has followed two lines of enquiry. One of them focuses on variations over time in the power of landed, noble families or Church institutions to enlarge estates forcefully or raise larger payments from the cultivators of the soil. Neither of the two camps opposing 
each other over this issue has as yet convincingly shown in which direction this potential contribution to economic inequality actually went. ${ }^{30}$

The second line concentrates on the state, a protagonist with far more complex motivations and outcomes-military, territorial, political and economic. Putting all of this together during the seventeenth and eighteenth centuries in Portugal, the balance may well have inclined to the side of a more equal distribution. Military endeavours on the whole were not intense drivers of expenditure that required heavier taxes. ${ }^{31}$ Wars were few and relatively low-cost. From the middle of the seventeenth century, the protection of the empire was partly defrayed by Britain, who guarded overseas maritime lanes. By the eighteenth century, substantial colonial revenues were alleviating the fiscal burden on the home country, while royal patronage in the empire kept the nobility on a short leash and discouraged excesses at home against the peasantry (Costa et al. 2016). In Portugal, it would seem that the greater and the lesser landlords depended for their livelihood considerably on a monarch who did not wish or need more extraction. This is, something, however, which still awaits further study.

\section{Conclusion}

This article uses a substantial new database to estimate economic inequality in Portugal on three different occasions in the early modern period-1565, 1700 and 1770. It comprises circa 140,000 households in twenty-seven observations across the country. In terms of content, the aim is to fill a gap in a flourishing literature with a little studied case and thus further the possibilities of comparative analysis in this field. In terms of method, its most important contribution is to show that long-term economic inequality and macroeconomic performance have much to gain from being researched jointly.

Several important steps had to be taken from the outset. One was to select a national measure in the spirit of Kuznets, rather than a regional or local one. A second was to calculate an index of income disparity which represented a 'cleaner' approach than one based on wealth. The third was to employ the best possible data, which was done by using, to a large extent, a set of precocious personal income tax rolls, complemented by a smaller and earlier set of taxes on rents. The fourth was to use a Theil rather than a Gini index so as to avoid problems of decomposition, which arise with the latter metric.

A parsimonious approach was followed since it would have been impossible to cover directly the entire country and all the years in the period under observation. It was also an 'additive strategy', which built up from four types of settlement, each one assumed to have stable inequality characteristics. For each benchmark, representatives of each of these types were then aggregated into weighted means to

\footnotetext{
30 For examples, see Neto (1997), on the one hand, and Salvado (2010), on the other.

31 Alfani (2015) shows how building up and unifying a military Piedmontese state in the sixteenth century forced the monarch to become more extractive.
} 
obtain a national Theil for every benchmark. All the data employed were checked for reliability, plausibility and biases.

The results were unexpected. They portray a downward sloping inequality profile which, as far as we know, to date has no equal in early modern European history. Thus far, all case studies have reported long-run rising inequality and, puzzlingly, this happens in conjunction, sometimes with growing economies, other times with stagnant or receding ones. To unravel this enigma, recourse was had to the four standard hypotheses that are usually followed in trying to explain the determinants of economic disparity. Three rely on quantitative tests; the fourth is descriptive and naturally less exact.

The best fit was provided by analysing factor-price ratios. It was found that between 1565 and 1770, a rent-wage index for Portugal, which proxies the relative scarcity of land and labour, tracked quite well the evolution of the inequality index. A test for the 'Williamson effect' yielded a somewhat weaker result but pointed in the same direction. The Kuznets model lacked explanatory power and an institutional approach appeared to corroborate the favoured methodology.

In terms of this era of European history, this outcome may seem inconsistent with the sustained demographic pressures which should have caused the opposite trend. The singularity, in this case, can be explained by a long wave of agriculture-based economic expansion during which the demand for labour mostly ran ahead of that for land. The highly labour-intensive type of cultivation that spread after 1600 and went on for a century and a half helps to explain this continuous absorption of labour without Malthusian effects. As a result, Portugal's fast growing population was able not only to enjoy a rising secular standard of living, but additionally to live for generations under conditions of declining inequality.

Acknowledgements The author wishes to thank Guido Alfani, Maria Antónia Pires de Almeida, Inês Amorim, Alda Azevedo, Raquel Berredo, Leonor Freire Costa, Rui Esperança, Carlos Faísca, João Ferrão, João Fialho, António Castro Henriques, Bruno Lopes, Filomena Melo, Conceição Andrade Martins, Esteban Niccolini, Álvaro Santos Pereira, Susana Pereira, Amélia Polónia, Isabel dos Guimarães Sá, João Paulo Salvado and Ana Margarida Silva, as well as the organisers and participants of the Economic History Society Conference, in Oxford, March 2012, the 3rd Einite Workshop on Economic Inequality in Southern Europe (Milan, Bocconi University, June 2015) and the Economic Inequality in Pre-industrial Eurasia session of the XVIIth World Economic History Congress (August 2016, Kyoto). He is especially grateful to Jeffrey G. Williamson and Peter H. Lindert for their encouragement and guidance. He is also indebted to the Fundação para a Ciência e Tecnologia for valuable financial support.

\section{References}

Alfani G (2015) Economic inequality in northwestern Italy: a long-term view (fourteenth to eighteenth centuries). J Econ Hist 75:1058-1096

Alfani G, Ammannati F (2016) Long-term trends in economic inequality: the case of the Florentine State (late thirteenth-early nineteenth centuries). Econ Hist Rev (forthcoming)

Alvaredo F (2008) Top incomes and earnings in Portugal 1936-2005. Explor Econ Hist 46:404-417

Alvarez-Nogal C, de la Prados de la Escosura L (2007) The decline of Spain (1500-1850): conjectural estimates. Eur Rev Econ Hist 11:319-366

Alvarez-Nogal C, Prados de la Escosura L (2013) The rise and fall of Spain (1270-1850). Econ Hist Rev $66: 1-37$ 
Bairoch P, Batou J, Chèvre P (1988) La Population des Villes Européennes, 800-1850. Librairie Droz, Geneva

Bértola L, Prados de la Escosura L, Williamson JG (2010) Latin American inequality in the long Run. Rev de Historia Economica J Iberian Lat Am Econ Hist 28(2):219-226

Broadberry S, Campbell B, Klein A, Overton M, van Leeuwen B (2015) British economic growth 1270-1870. Cambridge University Press, Cambridge

Canbakal H, Filiztekin A (2013) Wealth and inequality in Ottoman lands in the early modern period. In: Paper presented at the Rice University conference on the political economy of the muslim world

Conde AF (2002/3) O Mosteiro de S. Bento de Cástris e a décima eclesiástica. Revista Portuguesa de História XXXVI:161-172

Cortesão J (1964) Os factores democráticos na formação de Portugal. In Obras Completas 1:247-265

Cosgel M, Ergene B (2012) Inequality of wealth in the Ottoman Empire: war, weather, and long-term trends in eighteenth century Kastamonu. J Econ Hist 72:308-331

Costa AC (1708) Corografia e Descrição Topográfica do Famoso Reino de Portugal, vol 3. Valentim Deslandes, Lisboa

Costa CA (1851) Estatística Coordenada sobre os Arrolamentos da Décima Lançada em Diversos Concelhos do Districto de Lisboa. Imprensa Nacional, Lisboa

Costa LF (2009) Fiscal innovations in early modern states: which war did really matter in the Portuguese case? Working paper no 40, GHES/ISEG, Lisbon

Costa L, Lains P, Miranda S (2016) An economic history of Portugal, 1143-2010. Cambridge University Press, Cambridge

Cowell FA (2011) Measuring inequality. Oxford University Press, Oxford

Dominguez R (2015) La réalité: Les pedidos du Portugal et la collecte de recettes extraordinaires à la fin du Moyen Âge. In: Béguin K (ed) Ressources Publiques et Construction Étatique en Europe XIII ${ }^{\circ}-$ $\mathrm{XVIII}^{\circ}$ siècle. Comité pour l'histoire économique et financière de la France-IGPD, Paris, pp 49-66

Engerman SL, Sokoloff KL (1997) Factor endowments, institutions and differential paths of growth among new world economies: a view from economic historians of the United States. In: Haber S (ed) How Latin America fell behind. Essays on the economic histories of Brazil and Mexico, 1800-1914. Stanford University Press, Stanford, pp 260-304

Faísca CM, Lopes B (2015) Desigualdade de rendimento no Alentejo do Antigo Regime: Arraiolos, Avis e Portalegre (1690-1725). Análise Soc L:330-354

Fonseca HA (1996) O Alentejo no Século XIX: Economia e Atitudes Económicas. Imprensa NacionalCasa da Moeda, Lisboa

Franzini MM (1843) Considerações acerca da Renda Total da Nação Portuguesa e sua Distribuição por Classes com algumas Reflexões sobre o Imposto da Décima. Imprensa Nacional, Lisboa

Godinho VM [1971] (1980) Estrutura da Antiga Sociedade Portuguesa, 4th ed. Arcádia, Lisboa

Gonçalves I (1964) Pedidos e Empréstimos em Portugal durante a Idade Média. Ciência Técnica Fiscal, Lisboa

Guilera J (2010) The evolution of top income and wealth shares in Portugal since 1936. Revista de Historia Económica-Journal of Iberian and Latin American Economic History 28:139-171

Hanus J (2013) Real inequality in the early modern Low Countries: the city of 's-Hertogenbosch, 1500-1660. Econ Hist Rev 66:733-756

Hoffman P, Jacks D, Levin PA, Lindert P (2002) Real inequality in Europe since 1500. J Econ Hist 62:322-355

Johnson HB (2002) Teorias maltusianas confirmadas? Algumas reflexões sobre as alterações na distribuição da riqueza e rendimento em Portugal (1309-1789). In: Johnson HB (ed) Camponeses e Colonizadores: Estudos de História Luso-Brasileira. Estampa, Lisboa, pp 103-141

Kuznets S (1955) Economic growth and income inequality. Am Econ Rev XLV:1-28

Lains P, Gomes E, Guilera J (2008) Are dictatorships more unequal? Economic growth and wage inequality during Portugal's Estado Novo, 1944-1974. Working papers in economic history, Universidad Carlos III WP 08-08

Livro do Lançamento e Serviço que a Cidade de Lisboa fez a El Rei Nosso Senhor no Ano de 1565: Documentos para a História da Cidade de Lisboa (1947-8) (Lisboa: Câmara Municipal de Lisboa)

Magalhães JR (1970) Para o Estudo do Algarve Económico durante o Século XVI. Cosmos, Lisboa

Magalhães JR (1993) O Algarve Económico, 1600-1773. Estampa, Lisboa

Magalhães JR (2004) Dinheiro para a guerra: as décimas da Restauração. Hispania LXIV:157-182

Malanima P (2006) Pre-modern equality. Income distribution in the Kingdom of Naples (1811). Unublished paper presented at the International Congress of Economic History, Helsinki (2006) 
McCants A (2007) Inequality among the poor of eighteenth century Amsterdam. Explor Econ Hist 44(1): $1-21$

Milanovic B, Lindert PH, Williamson JG (2011) Pre-industrial inequality. Econ J 121:255-272

Morrisson C (2000) Historical perspectives on income distribution: the case of Europe. In: Atkinson AB, Bourguignon F (eds) Handbook of income distribution, vol 1. Elsevier, Amsterdam, pp 217-260

Morrisson C, Snyder W (2000) The income inequality of France in historical perspective. Eur Rev Econ Hist 4:59-83

Neto MS (1997) Terra e conflito: Região de Coimbra (1700-1834). Palimage, Viseu

Nicolini E, Ramos-Palencia F (2011) Comparing income and wealth inequality in pre-industrial economies. Lessons from Spain in the 18th century. Unpublished paper presented at the Iberometrics $\mathrm{V}$ meeting, Barcelona

Nicolini E, Ramos-Palencia F (2016) Decomposing income inequality in a backward pre-industrial economy: old castile (Spain) in the middle of the 18th century. Econ Hist Rev 69:747-772

O'Rourke KH, Williamson JG (2005) From Malthus to Ohlin: trade, industrialisation and distribution since 1800. J Econ Growth 10:5-34

Oliveira A (1971) A Vida Económica e Social de Coimbra de 1537 a 1640 (Coimbra: Faculdade de Letras da Universidade de Coimbra, 2 vols)

Palma N, Reis J (2016) From convergence to divergence: Portuguese demography and economic growth, 1500-1850. Groningen Growth and Development Centre Research Memorandum \#161. University of Groningen - Groningen Growth and Development Centre

Ribeiro O (1986) Portugal, o Mediterrâneo e o Atlântico. Estudo Geográfico, Lisbon

Rocha MM (1991) Níveis de fortuna e estruturas patrimoniais no Alentejo: Monsaraz, 1800-50. Análise Soc 26:629-651

Rocha MM (1996) Actividade credíticia em Lisboa (1770-1830). Análise Soc 31:579-598

Rodrigues JA (1968) Travail et societé urbaine au Portugal dans la seconde moitié du XVIe siècle', Ph.D. dissertation, University of Paris

Rodrigues JA (1970) Ecologia urbana de Lisboa na segunda metade do século XVI. Análise Soc 10:96-115

Ryckbosch W (2016) Economic inequality and growth before the industrial revolution: a case study of the Low Countries (Fourteenth-Nineteenth Centuries). Eur Rev Econ Hist 20:1-22

Sala i Martin X (2002) The disturbing 'rise' of global income inequality. National Bureau of Economic Research (NBER) working paper no. 8904. Cambridge: MA, April

Salvado JP (2010) Nobreza, monarquia e império: a casa senhorial dos Almotacés-mores do Reino (Séculos XVI-XVIII). Lisboa: Universidade Nova de Lisboa (Ph.D. dissertation)

Santiago-Caballero C (2011) Income inequality in Central Spain, 1690-1800. Explor Econ Hist 48:83-96

Serrão J (1969) Do Sebastianismo ao Socialismo em Portugal. Horizonte, Lisboa

Silva ÁF (1987) Família e trabalho doméstico no hinterland de Lisboa: Oeiras, 1763-1810. Análise Soc XXIII:531-562

Steckel RH, Moehling CM (2001) Rising inequality: trends in the distribution of wealth in industrializing New England. J Econ Hist 61:160-183

Tracy JD (2015) Taxation and state debt. In: Scott H (ed) The Oxford handbook of early modern history, 1530-1750, volume II - cultures and power. Oxford University Press, Oxford, pp 513-537

Van Zanden JL (1995) Tracing the beginning of the Kuznets curve: Western Europe during the early modern period. Econ Hist Rev XLVIII:643-664

van Zanden JL, van Leeuwen B (2012) Persistent but not consistent: the growth of national income in Holland 1347-1807. Explor Econ Hist 49:119-130

Williamson JG (2009) History without evidence: Latin American inequality since 1491, NBER working paper \#14766 Cambridge, MA 